\title{
DEPTH OF SEISMICITY IN THE IMPERIAL VALLEY REGION (1977-1983) AND ITS RELATIONSHIP TO HEAT FLOW, CRUSTAL STRUCTURE, AND THE OCTOBER 15, 1979, EARTHQUAKE
}

\author{
Diane I. Doser and Hiroo Kanamori
}

Seismological Laboratory, California Institute of Technology, Pasadena

\begin{abstract}
Focal depths from over 1000 earthquakes occuring between 1977 and 1983 in the Imperial Valleysouthern Peninsular Ranges are used to study relationships between the depth of seismicity, heat flow, and crustal structure. This study used relocated A and B quality events from the California Institute of Technology catalog that were carefully selected to insure focal depth precision of $\pm 2 \mathrm{~km}$. Regional variations in focal depth appear to be related to regional heat flow variation, whereas local variations in focal depth, especially in the central Imperial Valley, may be related to crustal structure. These variations are studied by rheologic modeling. A comparison of focal depths of earthquakes occurring before and after the October 15, $1979(\mathrm{M}=6.6)$, earthquake indicates that aftershocks during the first 2 months of the sequence were $2-3$ $\mathrm{km}$ deeper than earthquakes occurring in other time periods. The deepest earthquakes in Imperial Valley are spatially associated with a subbasement dome near the northern end of the Imperial fault. This dome coincides with the region where the Imperial fault undergoes a transition from stick-slip behavior to aseismic fault creep. Models of slip during the 1979 mainshock are also compared with premainshock and postmainshock seismicity. A relocation of the $1940(M=7.1)$ mainshock suggests that this sequence began by rupturing the same portion of the fault that experienced maximum slip during the 1979 mainshock.
\end{abstract}

\section{Introduction}

The Imperial Valley is one of the most seismically active regions of southern California. In this region, plate motion is transferred northward from the transform faultspreading center system of the Gulf of California to the San Jacinto and San Andreas fault zones along the Imperial fault and Brawley seismic zone (Figure 1) [Johnson, 1979].

A dense seismic network has been operating in the Imperial Valley-southern Peninsular Ranges since 1973 (Figure 2), with the implementation of automated processing in 1977. Although several seismicity studies have been conducted in the region [i.e., Gilpin and Lee, 1978; Combs and Hadley, 1977; Johnson and Hadley, 1976; Fuis and Schnapp, 1977; Hill et al. , 1975a, b], no previous study focused on the depth of seismicity across the entire area and related depth variation to crustal structure and heat flow. We relocated over 1500 earthquakes in the Imperial Valley-southern Peninsular Ranges occurring between 1977 and 1983. The final analysis compares focal depths to the crustal structure models of Fuis et al. [1982] and heat flow studies of Lachenbruch et al. [1985], using only those earth-

Copyright 1986 by the American Geophysical Union.

Paper number 5B5602.

0148-0227/86/005B-5602\$05.00 quakes that meet rigid location criteria outlined in a following section. We have modeled the depth to the brittle/ductile transition zone with appropriate thermal and compositional constraints.

A major earthquake $\left(\mathrm{M}_{\mathrm{L}}=6.6\right)$ occurred along the Imperial fault on October 15, 1979 (Figure 2), enabling a study of the variations in seismicity before and after the mainshock. We compared premainshock and postmainshock seismicity with dislocation models [Hartzell and Heaton, 1983; Archuleta, 1984] for the mainshock. We also relocated the 1940 earthquake sequence in an effort to determine what part of the Imperial fault ruptured during that earthquake and whether the rupture may have been controlled by any structures along the fault.

\section{Recent Seismicity}

The Imperial Valley-southern Peninsular Ranges study area (Figure 1) includes a major portion of the Salton Trough, extending from the U.S.-Mexican border near El Centro northward to Indio, and the southern end of the Peninsular Ranges that are bounded by the San Jacinto and Elsinore fault systems. Dibblee [1954] or Sharp [1972, 1982a) give a summary of the geologic and tectonic setting of the region. Figure 2 shows seismicity in this region from the California Institute of Technology (Caltech) catalog for 1977-1983.

The most seismically active area in the region is the Brawley seismic zone [Johnson, 1979] (Figures 1 and 2), where numerous swarms have occurred [Johnson and Hadley, 1976]. The Brawley seismic zone links the Imperial fault with the southern end of the San Andreas fault and possibly represents a spreading zone between these two strike-slip faults [Weaver and Hill, 1979]. Seismicity along the Superstition Hills and Superstition Mountain faults, which may be a southern extension of the San Jacinto fault system [Sharp, 1972], is diffuse. Diffuse seismicity also characterizes the Elsinore fault system. The San Jacinto fault system has distinct areas of high seismicity with an intervening gap in seismicity termed the Anza seismic gap [Sanders and Kanamori, 1984]. The San Andreas fault shows a notable lack of seismicity north of the Brawley seismic zone, a likely nucleation point for a major earthquake along this segment of the fault [Johnson and Hutton, 1982 .

Few recent studies of seismicity in the Imperial Valleysouthern Peninsular Ranges have had adequate data to determine accurately the focal depths. Gilpin and Lee [1978] and Combs and Hadley [1977] conducted microearthquake surveys with portable seismometers in geothermal areas in the Imperial Valley. Johnson and Hadley [1976] determined focal depths for several swarm sequences in the Brawley seismic zone, and Pechmann and Kanamori [1982] relocated selected aftershocks of the 1979 mainshock. Although these studies are not sufficient to determine regional or long-term temporal variations in focal depth, the depths can be used as a check on the depths obtained from our relocation process. 


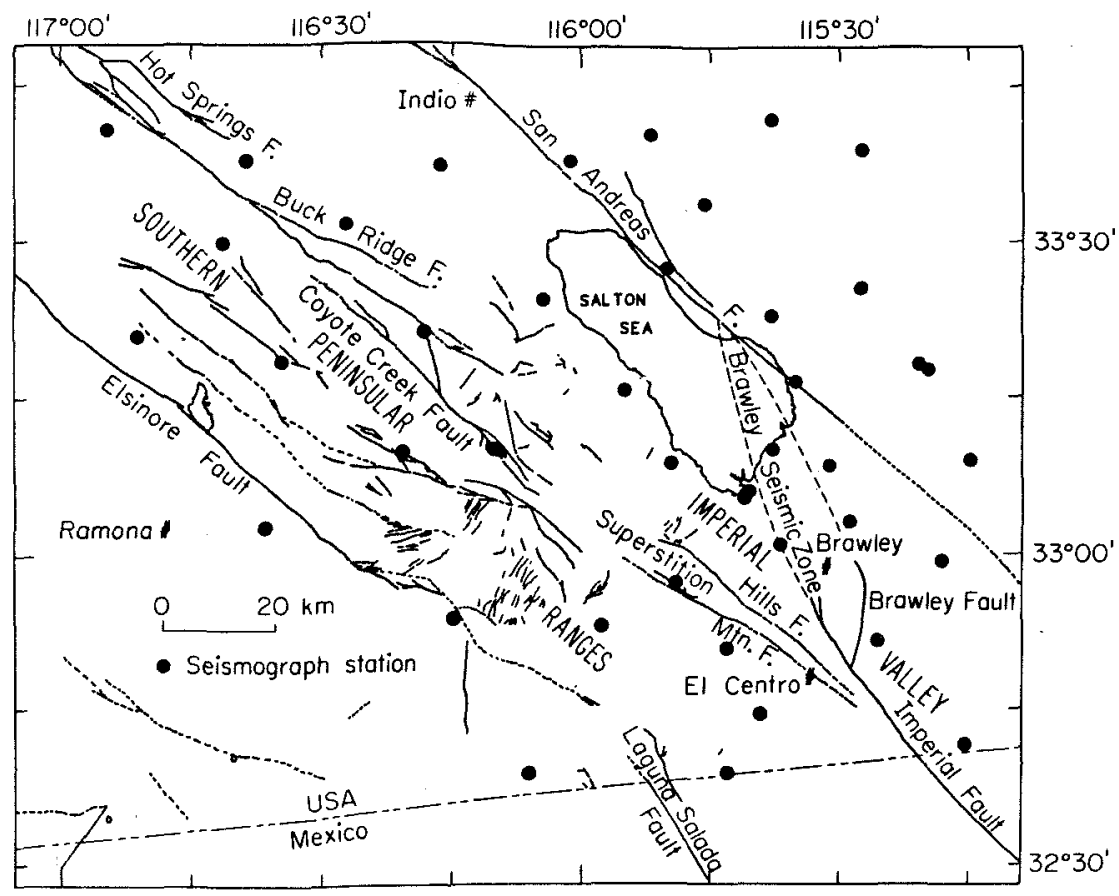

Fig. 1. Imperial Valley-southern Peninsular Ranges study area. Faults and regions discussed in the text are labeled. Seismograph stations operating in the region are shown as dots.

\section{Relocation Procedure}

A three-step process was used to relocate all earthquakes of $A$ and $B$ quality occurring between 1977 and 1983 in the study area. Earthquakes were relocated using a modified version of HYPO71 [Lee and Lahr, 1975] and the velocity models listed in Table 1 . Figure 2 shows the areas where each velocity model was used. The northern Imperial Valley, southern Imperial Valley, and lower Borrego Valley models are smoothed models obtained from the crustal models of Fuis et al. [1982]. The Borrego Valley model is from Hamilton [1970]. The locations used P wave arrivals from stations at epicentral distances less than 75 $\mathrm{km}$. A weight of one was used for stations at epicentral distances less than $50 \mathrm{~km}$, and the weights decreased linearly between 50 and $75 \mathrm{~km}$ to a weight of 0 at $75 \mathrm{~km}$.

First, the study area was divided into 35 subregions where each subregion contained a small group of earthquakes occurring in an area less than $20 \times 20 \mathrm{~km}$ in dimension. The earthquakes in the subregion were then relocated using the appropriate regional velocity model and no station delays. Next, median station delays and a median starting depth were obtained from the station residuals of the best relocations (A quality). These values were then used to relocate the events a second time. Finally, a master event was chosen from these relocated earthquakes, and a third relocation was made using the master event delays. All final relocations were started at the master event hypocenter location. The intermediate step in this procedure made the final relocations less sensitive to the choice of the master event. The final analysis used only those relocations that had rms $<0.15 \mathrm{~s}$, erh and erz $\leq 1.0 \mathrm{~km}$, distance to nearest station $\leq 1.5 \mathrm{x}$ focal depth, azimuthal gap $\leq 135^{\circ}$, and number of stations $>6$. Although 1513 earthquakes were initially relocated, only $1076(71 \%)$ of the relocations met the above location criteria. Comparisons of frequency-depth distribution curves for all relocated earthquakes with curves for the high-quality relocations (in the entire region and in subregions) show no significant varia- tions between curves. This indicates that bias is not being introduced into the analysis of focal depth variations by using only the high-quality relocations.

Several tests of location quality were performed. Internal tests included varying the number of earthquakes used to calculate median delays and choosing different master events for the final relocation. These variations changed focal depths by $1-2 \mathrm{~km}$. Earthquakes occurring between 1977 and 1983, in the subregion that encompassed the 1975 Brawley swarm sequence studied by Johnson and Hadley [1976], were relocated using their velocity model, station delays, and master events. The resulting focal depths were $2-3 \mathrm{~km}$ shallower than those obtained from our initial relocations, with maximum depths of $11-11.6 \mathrm{~km}$. Johnson and Hadley [1976] used a priori station delays in an effort to prevent the stations at the edge of the valley from biasing the focal depths of earthquakes within the valley. To determine whether or not these stations outside the valley were biasing our focal depths, we relocated the earthquakes in this subregion using only seismograph stations located in the portion of the Imperial Valley where there was no underlying crystalline basement [Fuis et al., 1982]. We did not add station delays because we felt that these stations were located above structure that was accurately modeled by the southern Imperial Valley velocity model. These focal depths were on the average $1 \mathrm{~km}$ shallower than the depths from our three-step relocation technique, regardless of the quality of the hypocenter, suggesting that the use of stations outside the valley to determine median delays did not bias the focal depths in this study more than the choice of the master event or stations used in the median delay calculations. Focal depths determined using Johnson and Hadley's model averaged $1.3 \mathrm{~km}$ shallower than the focal depths obtained using no delays and stations in the valley. Further testing suggested that Johnson and Hadley's station delays contributed the most to the focal depth difference. The focal depths of aftershocks of the 1979 earthquake relocated by Pechmann and Kanamori [1982] are within $\pm 2 \mathrm{~km}$ of the focal depths obtained in 


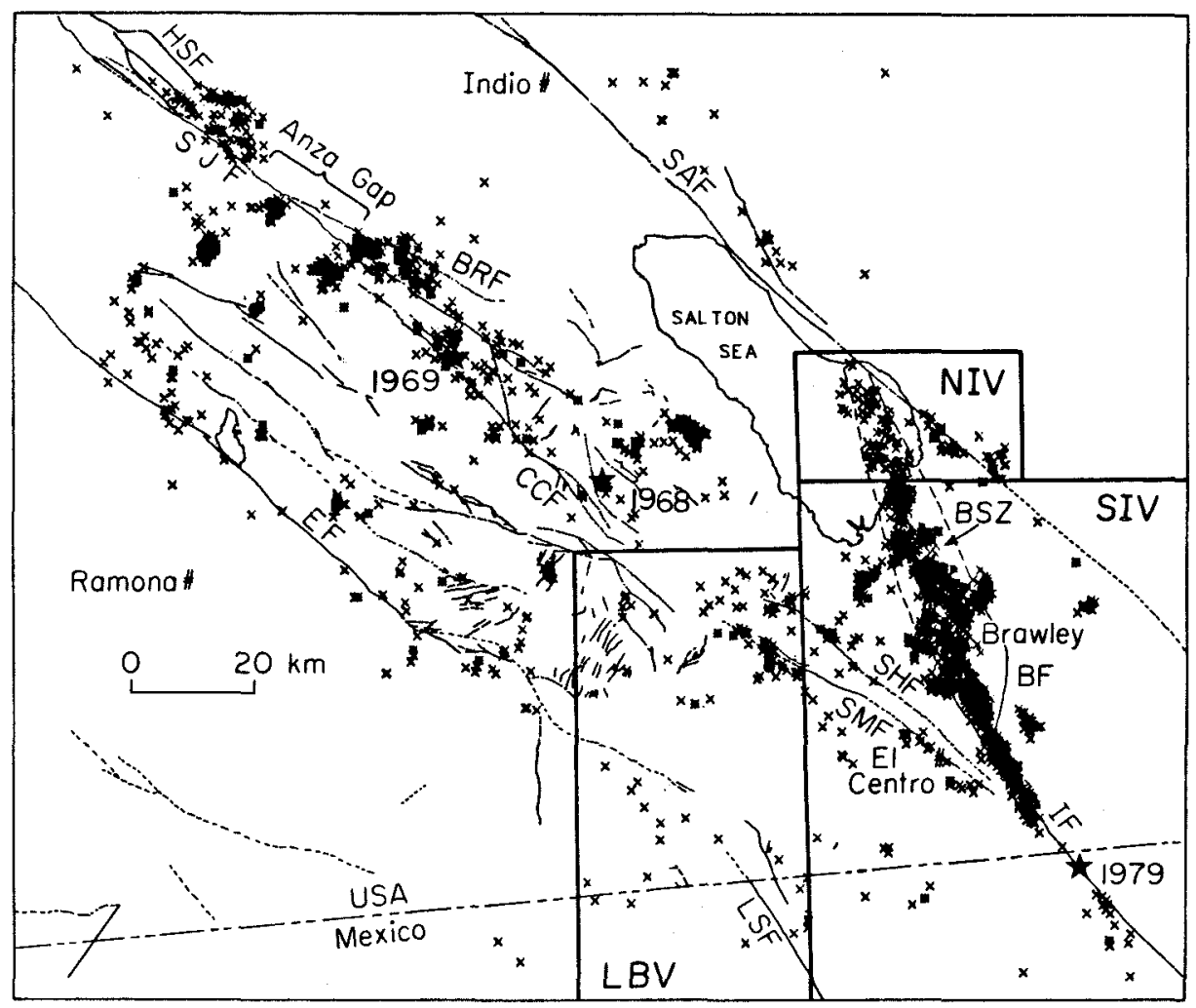

Fig. 2. A and B quality locations from the Caltech catalog. Boxes denote the areas where specific velocity models listed in Table 1 were used in the relocation process. NIV, Northern Imperial Valley; SIV, Southern Imperial Valley; LBV, Lower Borrego Valley. In the remaining unboxed area the Borrego Valley-Peninsular Ranges velocity model (Table 1) was used. The stars denote $\mathrm{M}_{\mathrm{L}}>5.5$ earthquakes occurring in the region during the last 20 years and include the Borrego Mountain (1968), Coyote Mountain (1969), and Imperial Valley (1979) earthquakes. The fault abbreviations used in this figure and following figures are: BF, Brawley fault; BRF, Buck Ridge fault; CCF, Coyote Creek fault; EF, Elsinore fault; HSF, Hot Springs fault; IF, Imperial fault; LSF, Laguna Salada fault; SAF, San Andreas fault; SHF, Superstition Hills fault; SJF, San Jacinto fault; SMF, Superstition Mountain fault; and BSZ, Brawley seismic zone. The shape of the symbol denotes earthquake magnitude. Crosses are $2.0 \mathrm{M}<3.0$, asterisks $3.0 \mathrm{M}<4.0$, circles $4.0 \mathrm{M}<5.0$.

this study. The above tests suggest that the focal depths of these selected relocated events have a precision of \pm 2 $\mathrm{km}$.

A major difference exists between depths of these relocated earthquakes and depths from the Caltech catalog. Focal depths are comparable (within 1-2 km) along the margins of the Imperial Valley and in the southern Peninsular Ranges; however, there are notable differences in focal depths in the Imperial Valley. The frequency-depth distribution curves for $A$ and $B$ quality catalog events in the Imperial Valley shows a maximum peak in frequency at 5 $\mathrm{km}$ with a secondary peak at $15 \mathrm{~km}$. The maximum depth of catalog events was $22.3 \mathrm{~km}$. The strong peak at $5 \mathrm{~km}$ appears to be related to the velocity model and technique used to locate catalog events. Locations are started at a depth of $5 \mathrm{~km}$, and there is a boundary in the velocity model at $5.5 \mathrm{~km}$. This causes events to artificially concentrate at $5 \mathrm{~km}$ in depth [Corbett, 1984]. The peak at $15 \mathrm{~km}$ may be related to a velocity model boundary at $16 \mathrm{~km}$ or the fact that the velocity model does not include the 3 - to 4-km-thick zone of low-velocity sedimentary fill that better models Imperial Valley structure. In contrast, the maximum depth of relocated earthquakes in the Imperial Valley was $13.2 \mathrm{~km}$, and the peak in the frequency-depth distribution curve was at $8 \mathrm{~km}$. Since the starting depth and velocity model varies in the subregions comprising the Imperial Valley, the observed regional peak should not be strongly related to these parameters.

Figure 3 shows all relocated, high-quality earthquakes. The size of the symbols in this and following figures reflects distance from the earthquakes to the nearest station. Comparison with the Caltech catalog earthquakes (Figure 2) shows several notable differences in distribution. About 500 earthquakes listed in the Caltech catalog could not be relocated because phase data recorded from May 1980 to early 1981 have not been entirely processed [Green, 1983]. In areas with poor station coverage such as parts of the Elsinore fault zone and the region northeast of the Salton Sea, earthquakes did not occur close enough to a station or have azimuthal coverage of $135^{\circ}$ or more to enable a precise focal depth determination. Some of the shallow seismicity associated with swarm sequences also was not close enough to a station to determine focal depths or had very high residuals. Overall, however, the general distribution of seismicity in the poorer-quality catalog data (Figure 2) is reflected in the higher-quality data of Figure 3. It appears that the use of the sorted relocated data is not introducing significant spatial bias in the data set. 
Table 1. Velocity Models Used in Earthquake Relocations

\section{P Wave Velocity, $\mathrm{km} / \mathrm{s} \quad$ Depth to Top of Layer, $\mathrm{km}$}

\begin{tabular}{|c|c|}
\hline \multicolumn{2}{|c|}{ Southern Imperial Valley } \\
\hline 2.0 & 0.0 \\
\hline 2.5 & 1.0 \\
\hline 3.0 & 1.8 \\
\hline 3.5 & 2.3 \\
\hline 4.0 & 3.0 \\
\hline 4.5 & 3.85 \\
\hline 5.0 & 4.15 \\
\hline 5.5 & 5.1 \\
\hline 5.8 & 6.0 \\
\hline 6.0 & 7.0 \\
\hline 6.3 & 8.0 \\
\hline 6.6 & 9.5 \\
\hline 7.0 & 11.5 \\
\hline 7.5 & 14.5 \\
\hline \multicolumn{2}{|c|}{ Northern Imperial Valley } \\
\hline 2.0 & 0.0 \\
\hline 2.5 & 0.4 \\
\hline 3.0 & 1.0 \\
\hline 3.5 & 1.8 \\
\hline 4.0 & 2.3 \\
\hline 4.5 & 3.0 \\
\hline 5.0 & 3.7 \\
\hline 5.5 & 4.2 \\
\hline 5.8 & 4.8 \\
\hline 6.0 & 5.7 \\
\hline 6.5 & 11.0 \\
\hline 7.0 & 14.5 \\
\hline \multicolumn{2}{|c|}{ Borrego Valley-Peninsular Ranges } \\
\hline 2.5 & 0.0 \\
\hline 5.1 & 0.4 \\
\hline 6.0 & 2.9 \\
\hline 6.5 & 10.0 \\
\hline 7.1 & 14.0 \\
\hline \multicolumn{2}{|c|}{ Lower Borrego Valley } \\
\hline $1: 8$ & 0.0 \\
\hline 2.0 & 0.5 \\
\hline 3.75 & 1.5 \\
\hline 5.5 & 2.0 \\
\hline 5.7 & 2.2 \\
\hline 6.0 & 4.7 \\
\hline 6.5 & 11.7 \\
\hline 7.0 & 12.3 \\
\hline 7.2 & 13.7 \\
\hline 7.5 & 16.0 \\
\hline
\end{tabular}

Relation of Earthquake Depths to Heat Flow and Crustal Structure

Figures 3, 4, and 5 show map views of the change of seismicity with depth in the study area. Figure 3 shows all relocated earthquakes and reflects the shallow seismicity of the region. As in Figure 2, the majority of seismicity lies in the Brawley seismic zone. Seismicity in the Imperial Valley outside this zone is diffuse and does not appear to concentrate along mapped surface faults. Seismicity is concentrated along distinct segments of the San Jacinto fault, and the Anza seismic gap is also visible.

A plot of earthquakes deeper than $10 \mathrm{~km}$ (Figure 4) shows that the deeper events in the Imperial Valley occur at the nothern end of the Imperial fault. Little seismicity occurs at depths greater than $10 \mathrm{~km}$ along the Coyote Creek-San Jacinto fault system or the northern end of the Brawley seismic zone. Most of the deeper seismicity concentrates along the San Jacinto-Buck Ridge and San Jacinto-Hot Springs fault systems northwest of the Imperial Valley.

Figure 5 shows earthquakes deeper than $12.5 \mathrm{~km}$. Only five earthquakes in the Imperial Valley region occur at this depth, and all are located at the northern end of the Imperial fault. The deepest earthquakes in this group occurred at a depth of $13.2 \mathrm{~km}$. A cluster of activity occurs along the San Jacinto-Hot Springs fault system as well as diffuse seismicity along the Elsinore fault. The deepest earthquakes in the Peninsular Ranges occurred at a depth of $16.7 \mathrm{~km}$ along the San Jacinto fault northwest of the Anza gap.

A cross section taken along the strike of the San Jacinto fault (Figure 6) shows variations in focal depth across the study area. Earthquakes located up to $10 \mathrm{~km}$ from the cross section line have been plotted. The deepest earthquakes in the section occur along the northwest end of the cross section with an average depth of $13 \mathrm{~km}$. There is a marked shallowing of seismicity south of the northwest end of the Anza gap to an average depth of $10 \mathrm{~km}$. (Earthquakes shown in the Anza gap in Figure 6 do not occur along the San Jacinto fault but are located $2-5 \mathrm{~km}$ southeast of the surface trace of the fault.) Approaching the Imperial Valley, the seismicity shallows to a maximum depth of $10 \mathrm{~km}$. An abrupt increase in depth occurs $10 \mathrm{~km}$ northwest of the Brawley fault in an $8-$ to $10-\mathrm{km}$-wide zone at the northern end of the Imperial fault. This suggests that slip at depth in the Imperial Valley is confined to this narrow band along the Imperial and Brawley faults. The apparent vertical trends of seismicity shown in Figure 6 are an artifact of the vertical exaggeration used in the cross section. Cross sections drawn without vertical exaggeration do not exhibit the lineations.

Figure 7 shows a plot of depth versus frequency of earthquakes. The seismicity in the Imperial Valley region (all earthquakes east of $116.25^{\circ} \mathrm{W}$ ) peaks at a depth of 8 $\mathrm{km}$, while in the southern Peninsular Ranges (west of $116.25^{\circ} \mathrm{W}$ ), seismicity peaks at a depth of $11 \mathrm{~km}$. This change in average focal depth reflects the variation in heat flow between the regions.

Figure 4 compares local and regional heat flow in the study area [Lachenbruch et al., 1985] to earthquakes deeper than $10 \mathrm{~km}$. Most of the Imperial Valley lies within the $100 \mathrm{~mW} / \mathrm{m}^{2}$ heat flow contour. The Brawley geothermal area is the only area where deeper earthquakes lie at the edge of a region with heat flow greater than $200 \mathrm{~mW} / \mathrm{m}^{2}$ (Figure 4). Earthquakes at depths of 8-9 km have been observed within 1-2 km of the Salton Sea geothermal area (Figure 4) [Gilpin and Lee, 1978], the largest and hottest geothermal area in the Imperial Valley [Renner et al. 1975]. This suggests that deeper earthquakes occurring near the edges of a geothermal area may not be unusual. The deepest seismicity in the Imperial Valley correlates with a heat flow low to the south of the Brawley geothermal area. Sass et al.[1984] believe that convective systems in the valley extend to depths of at least $2 \mathrm{~km}$; however, it is difficult to determine whether the correlation between the heat flow low and the deep seismicity is coincidental or signifies a deep convective system. The deepest seismicity occurs within the region where Fuis et al. [1982] have evidence for a dome on the subbasement (Figure 5).

Fuis et al. [1982] interpreted the crust of the Imperial Valley as being composed of an upper layer of sediments and sedimentary rocks with $\mathrm{P}$ wave velocities of 1.8-5.0 $\mathrm{km} / \mathrm{s}$, a transition zone into a section of basement composed of metasedimentary rocks $(5.6-6.6 \mathrm{~km} / \mathrm{s})$, and a final transition into a subbasement of gabbro or diabase with $\mathrm{P}$ 


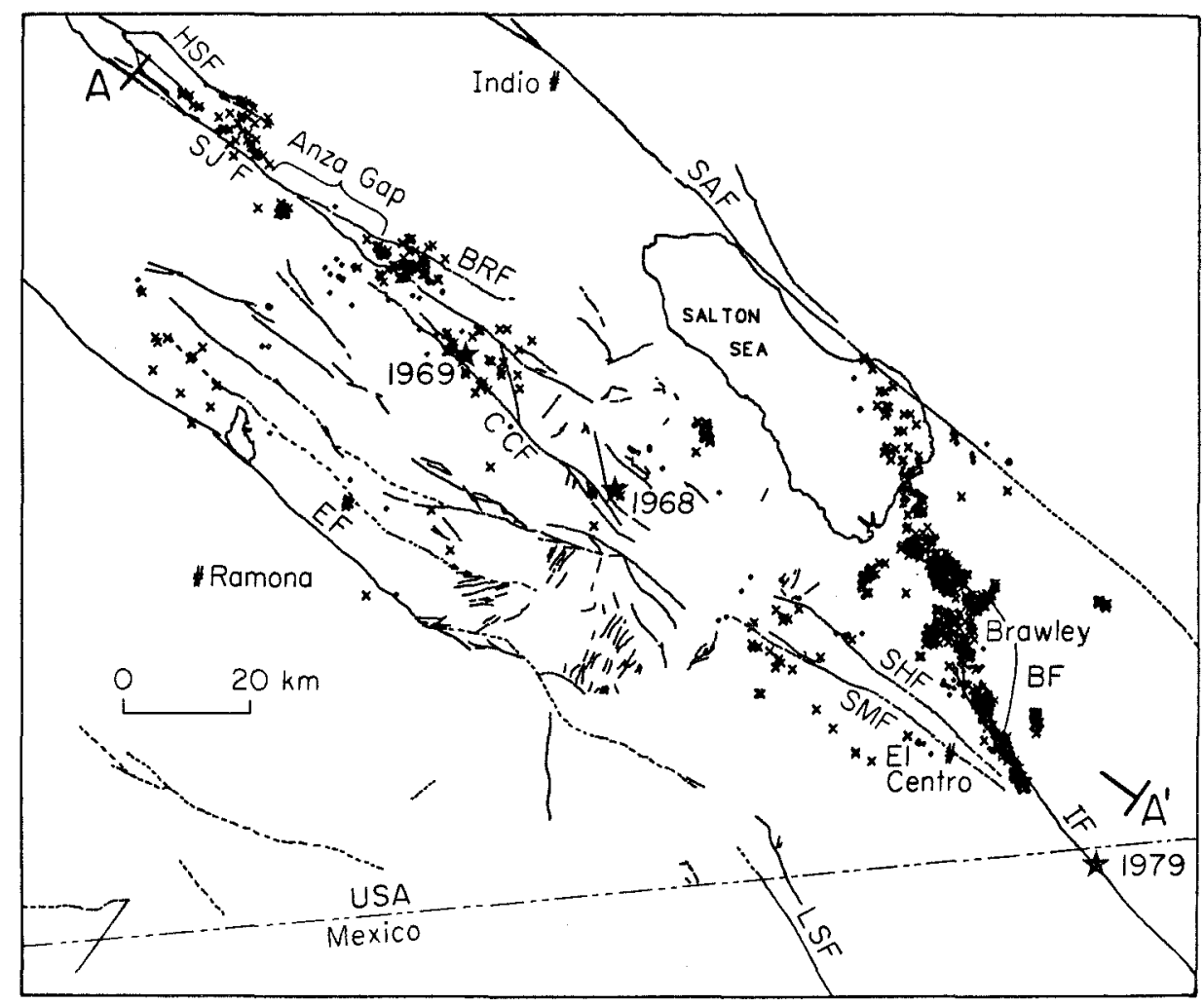

Fig. 3. All relocated earthquakes in study area. The type of symbol reflects the quality of location. Crosses are earthquakes with distance to the nearest station (dmin) hypocenter depth (depth), the smaller plusses are earthquakes with depth $<$ dmin $1.5 \mathrm{x}$ depth. A-A' is the location of the cross section shown in Figure 6.

wave velocities of $7.2 \mathrm{~km} / \mathrm{s}$. The depth to the transition between sedimentary and metasedimentary rocks is about $4 \mathrm{~km}$ in the portion of the valley where the deep seismicity is located. The depth to the transition between the metasedimentary rocks and the subbasement in this location is less certain. Fuis et al. $[1982]$ find some evidence for a dome on the subbasement at a depth of $11 \mathrm{~km}$ between Brawley and El Centro. The relief at the northern end of the dome is $5 \mathrm{~km}$ and at its southern end is about $1 \mathrm{~km}$. The uncertainty in resolving the depth to the subbasement is about $1 \mathrm{~km}$, and hence the southern edge of the dome is barely resolvable. If the dome does not exist, then the average depth to the subbasement would be about $13 \mathrm{~km}$.

Figure 8 shows a comparison of the crustal structure interpretations of $\mathrm{Fuis}$ et al. [1982] and relocated hypocenters along two refraction lines. Figure 5 shows the location of the refraction profiles. Line 6NNW-13SSE is a reversed profile that parallels the axis of the Salton Trough. Line 1ESE is an unreversed profile that cuts across the trough and the northern end of the Imperial fault. The approximate location of the postulated subbasement dome is also shown in Figure 8 . Note that earthquakes outside the domal area (cross section B-B') reach a maximum depth of $11 \mathrm{~km}$, while a large number of earthquakes within the domal area occur at depths of $11-13 \mathrm{~km}$. There is a marked shallowing of earthquakes to the northwest in profile B-B' near the Salton Sea geothermal area. Earthquakes also shallow to the southeast, suggesting that the dome may be related to the observed deeper earthquakes. All earthquakes in both profiles lie below the upper layer of sediments and sedimentary rocks. It is possible that some of the poorer-quality relocations not shown in these cross sections may have occurred at depths shal- lower than the sediments-metasediment boundary and were mislocated to deeper depths by HYPO71, which used a regression process that will drop the depth parameter first when attempting to iterate on a poor location. Other earthquake studies in the region, however, also found few earthquakes above this transition between sediments and metasediments. Johnson and Hadley [1976] found few earthquakes with depths above $4-5 \mathrm{~km}$. Gilpin and Lee [1978] found focal depths of $0.5-3.5 \mathrm{~km}$ within the Salton Sea geothermal area, but the few earthquakes located outside the geothermal area were deeper than $4 \mathrm{~km}$. Combs and Hadley's [1977] study of the Mesa geothermal area gives a similar depth distribution. These observations suggest that the minimum depth of seismicity in the Imperial Valley may be controlled by the depth to the transition zone between the sedimentary and metasedimentary layers. In areas of high heat flow $\left(>200 \mathrm{~mW} / \mathrm{m}^{2}\right)$ this transition zone may locally occur at depths shallower than $4 \mathrm{~km}$.

We have used several rheologic models to determine depth to the brittle/ductile transition zone in an effort to explain what possible temperature or structural effects may lead to the occurence of deeper earthquakes in the region immediately north of the end of the Imperial fault. Meissner and Strehlau [1982] have noted that about $80 \%$ of earthquakes in any given tectonic regime occur above this transition depth. This would suggest that the depth to the brittle/ductile transition in this small region of the Imperial Valley occurs at a depth of 11-12 km (Figure 9d) as obtained from frequency-depth distribution curves. Therefore we will be searching for the rheologic model that predicts a transition zone at this depth.

Shear resistance is calculated as a function of depth for strike-slip faulting (the predominate mode of faulting in 


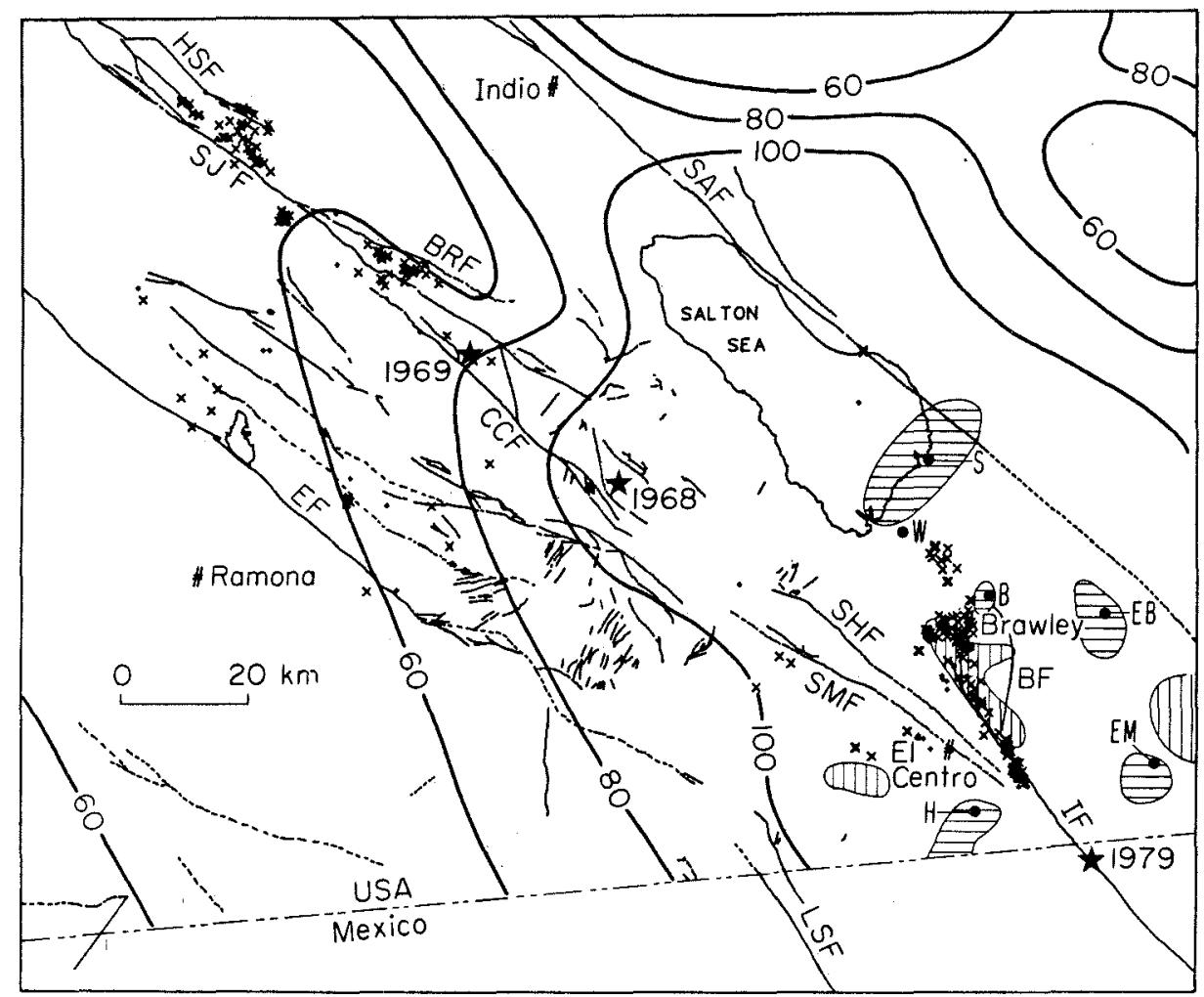

Fig. 4. Relocated earthquakes deeper than $10 \mathrm{~km}$ and regional heat flow [Lachenbruch et al., 1985] in the study area. The vertical stripes denote regions with heat flow $<100 \mathrm{~mW} / \mathrm{m}^{2}$, the horizontal stripes regions with heat flow $>200 \mathrm{~mW} / \mathrm{m}^{2}$. The letters associated with the dots are abbreviations for geothermal areas. B, Brawley; EB, East Brawley; EM, East Mesa; H, Heber; S, Salton Sea; and W, Westmorland.

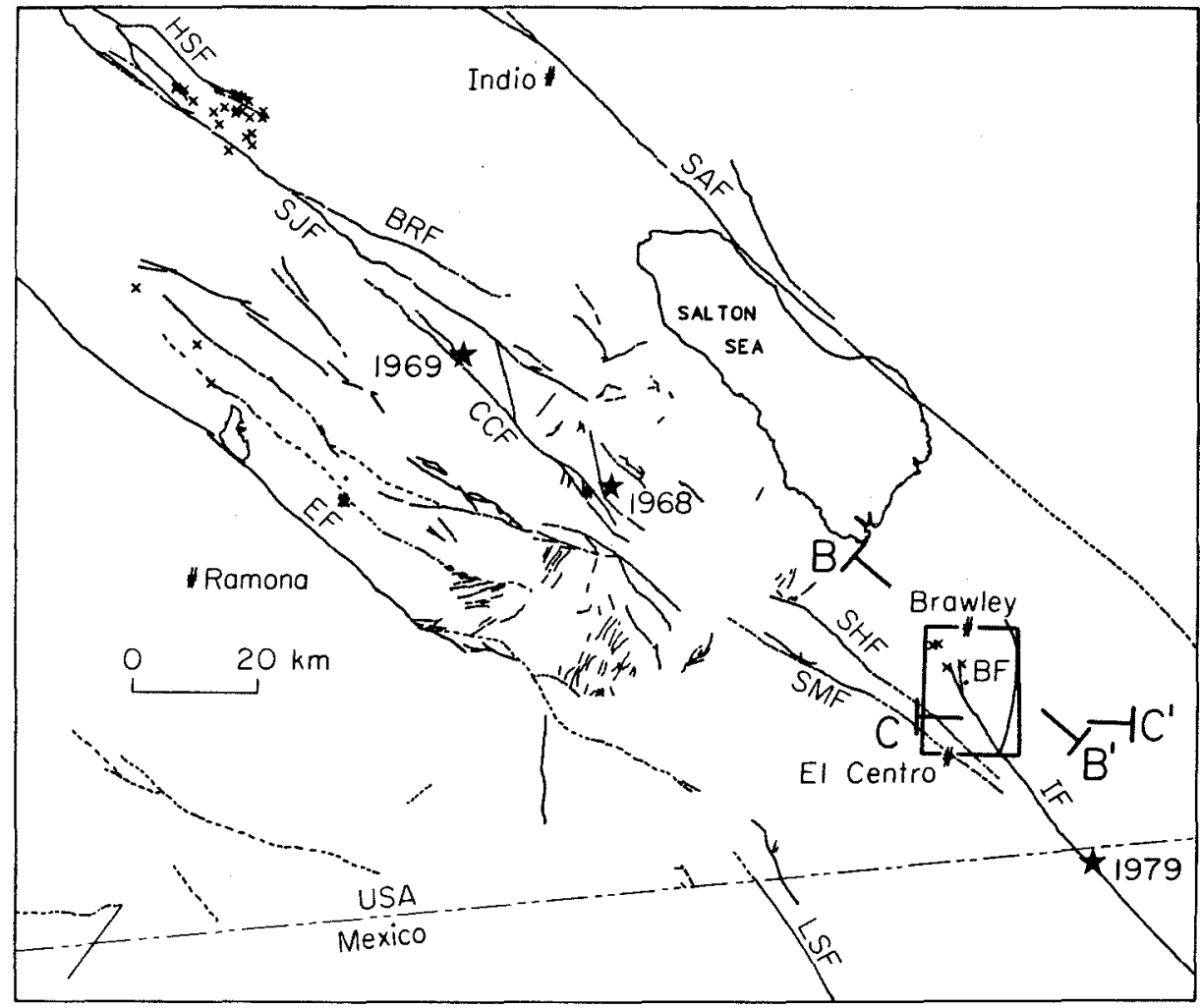

Fig. 5. Relocated earthquakes deeper than $12.5 \mathrm{~km}$. The box between Brawley and El Centro denotes the possible location of a subbasement dome as discussed by $F$ uis et al. [1982]. Cross-sections B-B' and $\mathrm{C}-\mathrm{C}^{\prime}$ are along the seismic refraction profiles of $\mathrm{Fuis}$ et al. [1982] and are shown in Figure 8. 


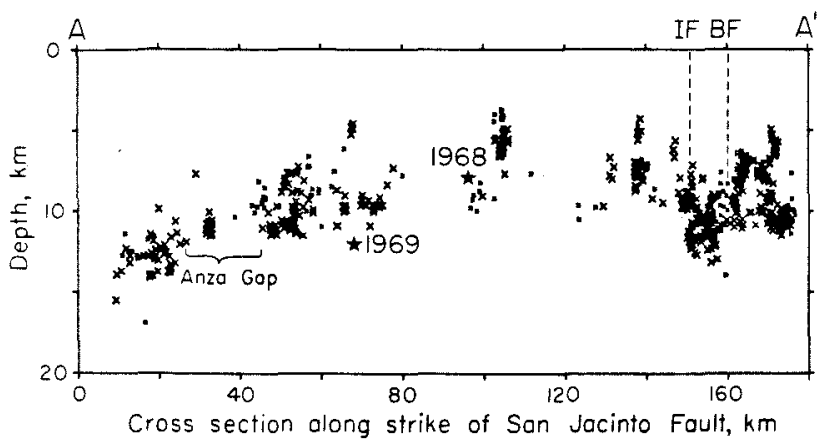

Fig. 6. Cross section of earthquakes along A-A'. The cross section follows the strike of the San Jacinto fault. (See Figure 3 for location.) Apparent lineations in the seismicity are a result of the scaling used in plotting and are not seen in larger-scale plots of the same region.

this part of the Imperial Valley) in a two-level model using the method of Sibson [1982]. In the upper level of the model, frictional faulting dominates, and in the lower level, quasi-plastic deformation dominates. Temperature is the dominant parameter controlling the transition between these zones.

The maximum shear resistance $\tau$ required to initiate frictional sliding on favorably oriented strike-slip faults in the upper level of the model is calculated from Sibson [1974]:

$$
\tau=1 / 2\left(\sigma_{1}-\sigma_{3}\right) \sin 2 \theta
$$

where $\sigma_{1}$ and $\sigma_{3}$ are the horizontal maximum and minimum compressive stresses, $\theta$ is the angle between $\sigma_{1}$ and the fault plane, and $\sin 2 \theta=\left(1+\mu^{2}\right)^{-1 / 2}$, with $\mu$ equal to the coefficient of static friction $(\simeq 0.75)$. In areas dominated by strike-slip faulting the value $\left(\sigma_{1}-\sigma_{3}\right)$ can be estimated from [Sibson, 1974]

$$
\left(\sigma_{1}-\sigma_{3}\right) \geq 6 / 5 \rho \mathrm{gz}(1-\lambda)
$$

where $\rho$ is the crustal density, $\mathrm{g}$ is the acceleration of gravity, $z$ is the depth, and $\lambda$ is the pore fluid factor. Under hydrostatic pressures, $\lambda$ is the ratio of the density of water to the average density of crustal rocks $(\simeq 0.36)$. Equation (2) assumes that $2 \sigma_{2}=\sigma_{1}+\sigma_{3}$ for strike-slip faults, where $\sigma_{2}$ is the intermediate principal compressive stress.

In the lower level where quasi-plastic deformation dominates, $\tau$, the maximum shear resistance, is $1 / 2\left(\sigma_{1}-\sigma_{3}\right)$ [Sibson, 1982], where $\left(\sigma_{1}-\sigma_{3}\right)$ is calculated from [ Turcotte and

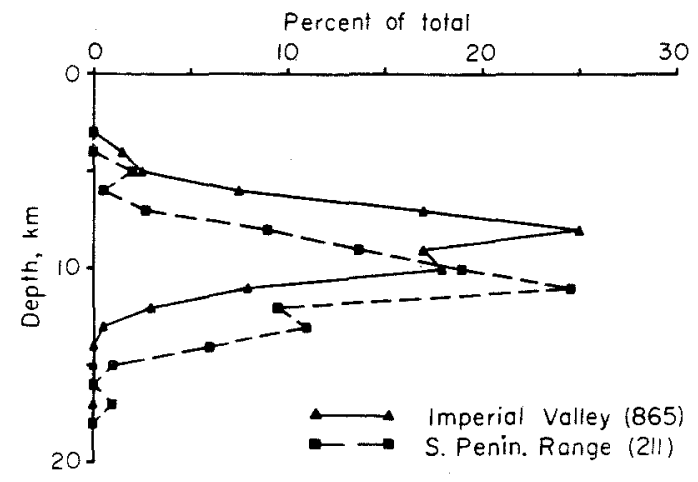

Fig. 7. Frequency-depth distribution of earthquakes in the Imperial Valley and southern Peninsular Ranges (latitude $\left.>116.25^{\circ} \mathrm{W}\right)$. The numbers in parentheses are the number of earthquakes used in the distribution determinations.
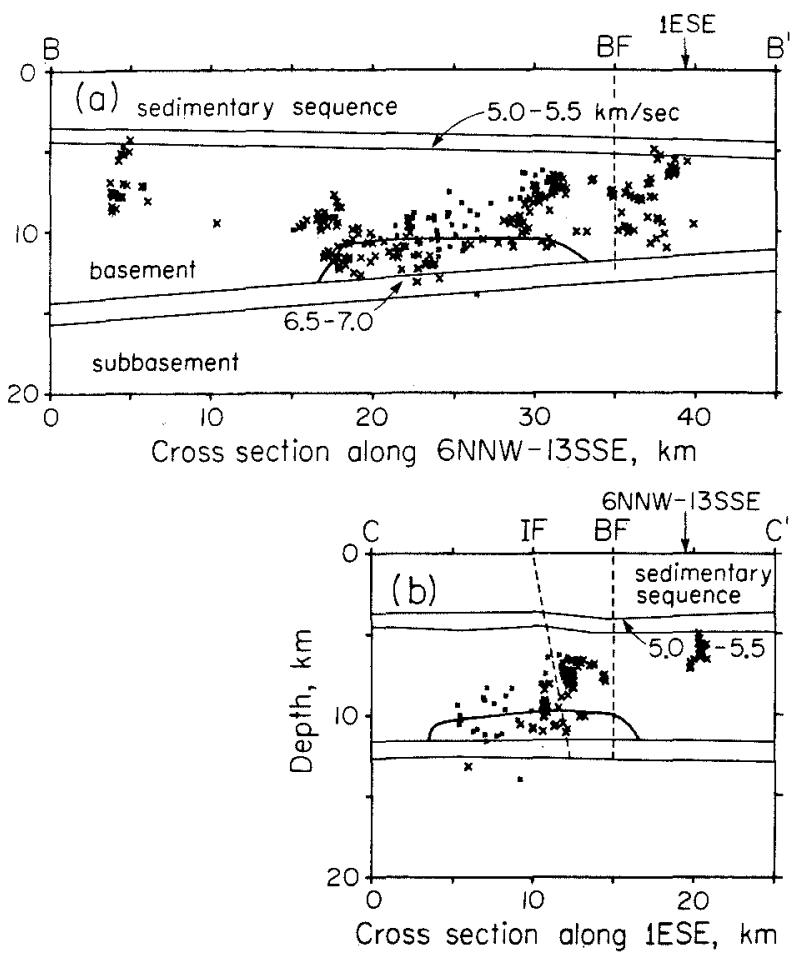

Fig. 8. Cross sections along $\mathrm{B}-\mathrm{B}^{\prime}$ and $\mathrm{C}-\mathrm{C}^{\prime}$ (see Figure 5 for location) showing the crustal interpretations of $\mathrm{Fuis}$ et al. $[1982]$ for lines 6 NNW-13SSE (B-B') and 1ESE (C-C'). The location of the subbasement dome described by Fu is et al. [1982] is also shown. Arrows show the point of intersection between the cross sections.

Schubert, 1982, p. 327]

$$
\left(\sigma_{1}-\sigma_{3}\right)^{\mathrm{n}}=\dot{\epsilon} /\left[\mathrm{A}^{\prime} \exp (-\mathrm{Q} / \mathrm{R} \mathrm{T})\right]
$$

where $\dot{\epsilon}$ is the strain rate, $R$ is the universal gas constant, $Q$ is the activation energy, $A^{\prime}$ is a material constant, and $T$ is the absolute temperature. To calculate temperature
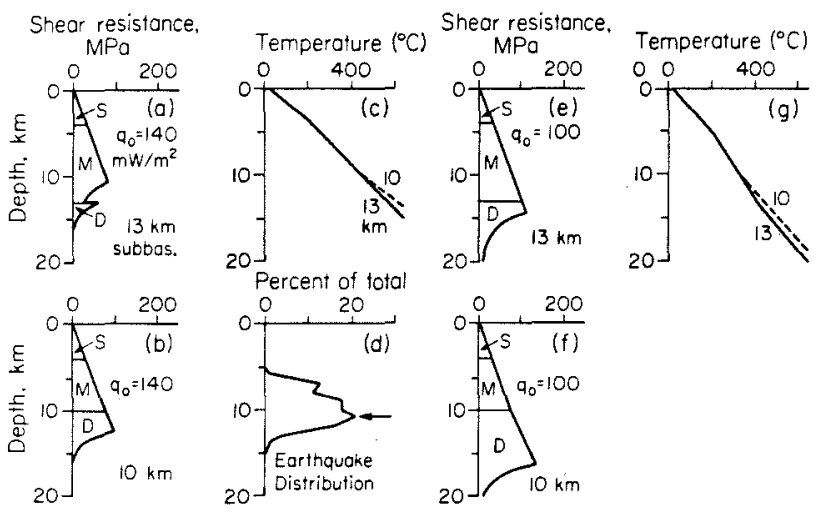

Fig. 9. Models of depth to the brittle/ductile transition zone. Shear resistance $(\tau)$ is plotted versus depth for four different models (Figures 9a-9d), where $S$ is the sediment layer, $M$ is metasediments (basement), and $D$ is diabase (subbasement). Temperature is plotted versus depth for these models in Figures $9 \mathrm{c}$ and $9 \mathrm{~g}$. The profile in Figure 9d shows the earthquake frequency-depth distribution for the region encompassed by the subbasement dome (Figure 5). Eighty percent of the earthquakes in the region occur above the depth of $11 \mathrm{~km}$ shown by the arrow. 
Table 2. Parameters Used in Rheologic Modeling

\begin{tabular}{|c|c|c|c|c|c|c|}
\hline n, power & $\begin{array}{c}\text { Activation } \\
\text { Energy Q, } \\
\mathrm{kJ} / \mathrm{mol}\end{array}$ & $\begin{array}{c}\text { Quasi-Plastic } \\
\text { Flow Constant } \\
\mathrm{A}^{\prime} \\
\mathrm{MPa}^{-\mathrm{n}} / \mathrm{s}\end{array}$ & Material & $\begin{array}{l}\text { Thermal } \\
\text { Conductivity } \mathrm{k} \text {, } \\
\mathrm{W} / \mathrm{m}^{\circ} \mathrm{K}\end{array}$ & $\begin{array}{c}\text { Radioactive } \\
\text { Heat Production } \\
\mathrm{A} \\
\mu \mathrm{W} / \mathrm{m}^{2}\end{array}$ & $\begin{array}{c}\text { Density } \\
\rho \\
\mathrm{kg} / \mathrm{m}^{3}\end{array}$ \\
\hline 3.0 & 190.0 & $5 \times 10^{-6}$ & Sediments & 2.9 & 1.45 & $2.45 \times 10^{3}$ \\
\hline 3.0 & 190.0 & $5 \times 10^{-6}$ & $\begin{array}{l}\text { Metasediments } \\
\text { (sandstone) }\end{array}$ & 3.3 & 1.5 & $2.65 \times 10^{3}$ \\
\hline 3.0 & 356.0 & $5.2 \times 10^{2}$ & $\begin{array}{l}\text { Subbasement } \\
\quad \text { (gabbro diabase) }\end{array}$ & 2.2 & 0.1 & $3.1 \times 10^{3}$ \\
\hline 2.9 & 105.8 & $1.26 \times 10^{-9}$ & Granite & 2.7 & 2.3 & $2.65 \times 10^{3}$ \\
\hline
\end{tabular}

as a function of surface heat flow and depth, we use

$$
\mathrm{T}=\mathrm{T}_{\mathrm{o}}+\mathrm{q}_{\mathrm{o}} \mathrm{z} / \mathrm{k}+\mathrm{Az} \mathrm{z}^{2} / 2 \mathrm{k}
$$

where $T_{0}$ is the average surface temperature, $q_{0}$ the surface heat flow, $k$ the thermal conductivity, and $A$ the radioactive heat production. In the Imperial Valley, $\mathrm{T}_{\mathrm{o}}=25^{\circ} \mathrm{C}$ [Lachenbruch et al, 1985]. Temperature profiles are computed for two different crustal models (a model with and without a subbasement dome) and two different surface heat flow values (average Imperial Valley heat flow of 140 $\mathrm{mW} / \mathrm{m}^{2}$ and a heat flow low of $100 \mathrm{~mW} / \mathrm{m}^{2}$ ). Table 2 lists the parameters used in the modeling process.

In the rheologic modeling we have assumed that the upper layer is alluvium with thermal properties measured by Sass et al. [1984] (Table 2). The metasedimentary rocks are interpreted as consisting of a sandstone in a low grade of metamorphism, and the subbasement is assumed to be a diabase. Thermal properties for the diabase and sandstone are from Clark [1966] and Clark et al. [1966] (Table 2). Material properties for quasi-plastic flow models have not been measured for many materials. Parameters for a quartz [Brace and Kohlstedt, 1980] were used for the sedimentary and metasedimentary rocks, and parameters for a Maryland diabase [Caristan, 1982] are used for the subbasement (Table 2). Since we are studying earthquake depth variations along the southern San Andreas and Imperial Valley faults, the strain rate was estimated to be $10^{-12} \mathrm{~s}^{-1}$, a value similar to that used by Sibson [1982] for the central San Andreas fault. This corresponds to a slip rate of about $1 \mathrm{~cm} / \mathrm{yr}$ across a shear zone $300 \mathrm{~m}$ wide. Rheologic models are calculated using an average Imperial Valley heat flow of $140 \mathrm{~mW} / \mathrm{m}^{2}$ [Lachenbruch et al., 1985] and a heat flow of $100 \mathrm{~mW} / \mathrm{m}^{2}$, as observed at the surface of the region of deeper seismicity. The higher heat flow model thus assumes that the low observed surface heat flow is a shallow effect of groundwater circulation, and that below this circulation zone, heat flow is comparable to other parts of the valley.

Thermal and compositional parameters are well constrained in the Imperial Valley; therefore the most significant source of error in the modeling process is the estimation of power law creep parameters. Smith and Bruhn [1984] have reviewed the resolution and uncertainty of rheological models and suggest that uncertainties in power law creep parameters may produce errors of tens of percent. A conservative estimate of error in the depth to the brittle/ductile transition zone would be about $2-3 \mathrm{~km}$.

Figure 9 shows the results of the rheologic modeling. For a heat flow of $140 \mathrm{~mW} / \mathrm{m}^{2}$ and a $13-\mathrm{km}$ depth to the subbasement (Figure $9 \mathrm{a}$ ) the brittle/ductile transition zone is at $10 \mathrm{~km}$. For a heat flow of $140 \mathrm{~mW} / \mathrm{m}^{2}$ and a sub- basement dome at a depth of $10 \mathrm{~km}$ (Figure $9 \mathrm{~b}$ ) the depth to the brittle/ductile transition zone is at $12 \mathrm{~km}$. Models with $q_{0}=100 \mathrm{~mW} / \mathrm{m}^{2}$ (Figures $9 \mathrm{e}$ and $9 \mathrm{f}$ ) have brittle/ductile transition zones at depths of 14 and $16 \mathrm{~km}$. It is important to emphasize that uncertainties in the model parameters may change the transition zone depths by several kilometers. If the metasedimentary rocks have rheological properties similar to quartzites, then the depth to the brittle/ductile transition may increase by 1 or $2 \mathrm{~km}$ [Smith and Bruhn, 1984]. High fluid pressures may also be present in certain areas of the Imperial Valley and could contribute to the deepening of the transition zone by several kilometers [Sibson, 1982]. However, the modeling does suggest that the subbasement high alone could depress the depth to the brittle/ductile transition in this region and that the heat flow low model need not be invoked to explain the deeper seismicity. It is possible that a combination of effects may lead to the deeper seismicity. Further studies of local crustal structure would help to determine the extent of the dome and its relationship to the deep seismicity. Measurements of fluid pressures would provide needed data to evaluate the role that pore pressure plays in deepening the seismogenic zone. Additional heat flow measurements near the dome would also help to resolve the extent and the depth of the heat flow low and its contribution to deepening the brittle/ductile transition zone.

Deep seismicity in the Peninsular Ranges (Figure 4) appears to occur primarily in regions with heat flow of 80 $\mathrm{mW} / \mathrm{m}^{2}$ or less. The deepest earthquakes occur in the $<$ $60 \mathrm{~mW} / \mathrm{m}^{2}$ heat flow region. It is interesting to note that the $1968\left(\mathrm{M}_{\mathrm{L}}=6.8\right)$ Borrego Mountain earthquake occurred along the Coyote Creek fault in an area with heat flow of $>100 \mathrm{~mW} / \mathrm{m}^{2}$. The focal depth of this earthquake was 8 $\mathrm{km}$ [Ebel and Helmberger, 1982]. Most aftershocks of this earthquake occurred at depths less than $8 \mathrm{~km}$, although a few aftershocks did occur to depths of up to $13 \mathrm{~km}$ [Hamilton, 1972]. This is in contrast to the $1969\left(\mathrm{M}_{\mathrm{L}}=5.8\right)$ Coyote Mountain earthquake that occurred northwest of the Borrego Mountain earthquake on the Coyote Creek fault in an area with heat flow $\simeq 80 \mathrm{~mW} / \mathrm{m}^{2}$. The focal depth for the Coyote Mountain event was about $12 \mathrm{~km}$, and aftershocks were concentrated at depths of $10-14 \mathrm{~km}$ [Thatcher and Hamilton, 1973]. This suggests that variations in heat flow may, in part, control the depths of seismicity in these regions. Sanders and Kanamori [1984] have suggested that high normal stresses from the uplift of the Coyote Ridge block northeast of the Coyote Creek fault may have prevented the occurrence of aftershocks at shallow depths following the Coyote Mountain earthquake. Seismicity in the region between 1977 and 1983, however, 


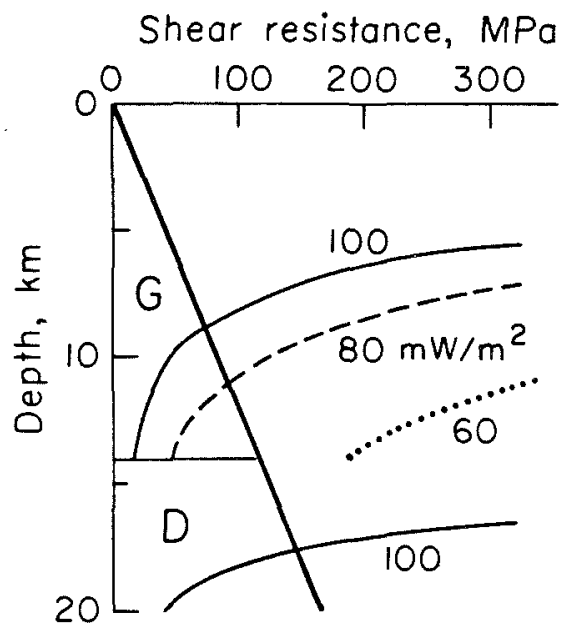

Fig. 10. Models of depth to the brittle/ductile transition zone in the southern Peninsular Ranges. Shear resistance versus depth is shown for three different geotherms. G, granite; $\mathrm{D}$, diabase.

ranges from 5 to $11 \mathrm{~km}$, indicating either that the stress field has changed in the years following the Coyote Mountain earthquake or that another factor controlled the depth of the 1969 aftershocks.

Although little is known about the crustal composition and structure of the southern Peninsular Ranges, the depth to the brittle/ductile transition zone is estimated using a simplistic crustal model and three different crustal geotherms. Hamilton [1970] conducted a seismic refraction study in the Borrego Mountain region and interpreted the crust to consist of a thin $(0.4 \mathrm{~km})$ layer of alluvium overlying a thick $(12-14 \mathrm{~km})$ granitic layer. Below the granite lies a subbasement of undetermined composition with a $P$ wave velocity of $7.1 \mathrm{~km} / \mathrm{s}$. Hamilton also noted that there appeared to be considerable variation in the thickness of the alluvial layer and the granitic layer. It is uncertain whether this crustal structure is applicable to the northern part of the study area. In the rheologic model the crust is assumed to be composed of a 14-km-thick granite over a diabase. Thermal parameters for the granite are taken from Clark [1966], and quasi-plastic flow parameters are for a Westerly granite (Table 2) [Brace, 1965]. The diabase has the same parameters as used in the Imperial Valley models. The strain rate was again estimated to be $10^{-12}$ $\mathrm{s}^{-1}$

Depths to the brittle/ductile transition zone for this model are shown in Figure 10 . Note that $80 \%$ of the earthquakes in the Peninsular Ranges occur above a depth of $11-12 \mathrm{~km}$. Two of three rheologic models (the 100 $\mathrm{mW} / \mathrm{m}^{2}$ and $80 \mathrm{~mW} / \mathrm{m}^{2}$ models) for the Peninsular Ranges show two brittle/ductile transition zones, one in the granite and one in the diabase. The second transition zone for the $100 \mathrm{~mW} / \mathrm{m}^{2}$ model occurs at a depth of $18 \mathrm{~km}$. Note that the second transition zone for the $80 \mathrm{~mW} / \mathrm{m}^{2}$ model is not shown in Figure 10. It occurs at a depth of $22 \mathrm{~km}$. Double seismic zones (e.g. two brittle/ductile transition zones) are not observed in the region, suggesting that the composition of the lower crust may not be adequatley modeled or that other parameters, such as the strain rate, may not be appropriate for the region. The brittle/ductile transition in the granite occurs at depths greater than $9 \mathrm{~km}$. The 100 $\mathrm{mW} / \mathrm{m}^{2}$ model, aside from the second transition zone, agrees well with the distribution of aftershocks for the Borrego Mountain earthquake and the heat flow contours of Figure 4. The granitic brittle/ductile transition zone for the $80 \mathrm{~mW} / \mathrm{m}^{2}$ model agrees well with the observed regional earthquake depth-frequency curve. The 60 $\mathrm{mW} / \mathrm{m}^{2}$ model does not show a brittle/ductile transition zone in the granite and appears appropriate for the deepest area of earthquakes observed northwest of the Anza gap where the events may be occurring in the upper part of the diabase layer.

\section{Spatial Variations in Seismicity Associated with the October 15, 1979, Earthquake}

The earthquake of October 15, $1979(\mathrm{M}=6.6)$, is the largest earthquake to have occurred in Imperial Valley since 1940. The earthquake epicenter is located along the Imperial fault about $3 \mathrm{~km}$ to the south of the U.S.-Mexican border, and the focal depth of the earthquake has been estimated to be $8 \mathrm{~km}$ [Archuleta, 1982]. Rupture during the mainshock was predominately to the northwest, although Anderson and Silver [1985] give evidence for a small component of southeastward rupture. Surface faulting was mapped along the Imperial fault from a point $8 \mathrm{~km}$ northwest of the mainshock epicenter to a point $38 \mathrm{~km}$ northwest of the epicenter (Figure 11) [Sharp et al., 1982]. Johnson and Hutton [1982] give a detailed description of the aftershock sequence and preearthquake seismicity.

Figure 11 compares relocated epicenters for three periods, July 1977 to October 15, 1979; October 15 to December 15, 1979; and post-December 15, 1979, to December 31,1983 . Although these maps do not show a complete picture of seismicity during these time periods (especially along the border where station coverage is not adequate to determine precise focal depths), there are several notable differences in the relocated and Caltech catalog seismicity of these time periods. Premainshock seismicity occurs along the entire length of the Brawley seismic zone as well as along the Superstition Hills and Superstition. Mountain faults. The northern end of the Imperial fault from $5 \mathrm{~km}$ southeast of $\mathrm{El}$ Centro to the north is seismically active. Aftershock activity is primarily confined to the extreme northern part of the Imperial fault and to a cluster of, activity near El Centro. There is a lack of seismicity to the immediate northwest of the 1979 mainshock (seen also in the catalog data) and in the region between the El Centro cluster and the northern end of the fault. Aftershocks also occur east of the Brawley seismic zone in an area that was aseismic prior to the mainshock These patterns of seismicity are also seen in the locations of Johnson and Hutton [1982]. Postmainshock activity shows seismicity along the Superstition Hills and Superstition Mountain faults, the continuance of seismicity to the east of the Brawley seismic zone, and swarms west of the Salton Sea and near Westmorland. Few earthquakes occur along the Imperial fault, although this may be a reflection of the gap in the data set between 1980 and 1981. Seismicity near the southern end of the San Andreas fault did not change significantly during this study period. Johnson and Hutton [1982] identified this region as a likely nucleation point for the next large earthquake along this fault Most earthquakes occurred at depths of 6-7 $\mathrm{km}$ near the fault under the Salton Sea. Two aftershocks occured at the northern end of the Brawley seismic zone with depths of $10.5 \mathrm{~km}$ and were the deepest events observed in the region.

Figure 12 shows the frequency-depth distribution of earthquakes for these three time periods. For all earth quakes studied the premainshock and post-December 15, 1979 , earthquakes show depth peaks at 8 and $7 \mathrm{~km}$. Aftershocks showed peaks at 8 and $10-\mathrm{km}$, with the $10 \mathrm{~km}$ peak being somewhat larger. At larger magnitudes the distributions change little, except that for aftershocks with $M \geq 3.0$ the distribution peaks at $8 \mathrm{~km}$ instead of $10 \mathrm{~km}$. 

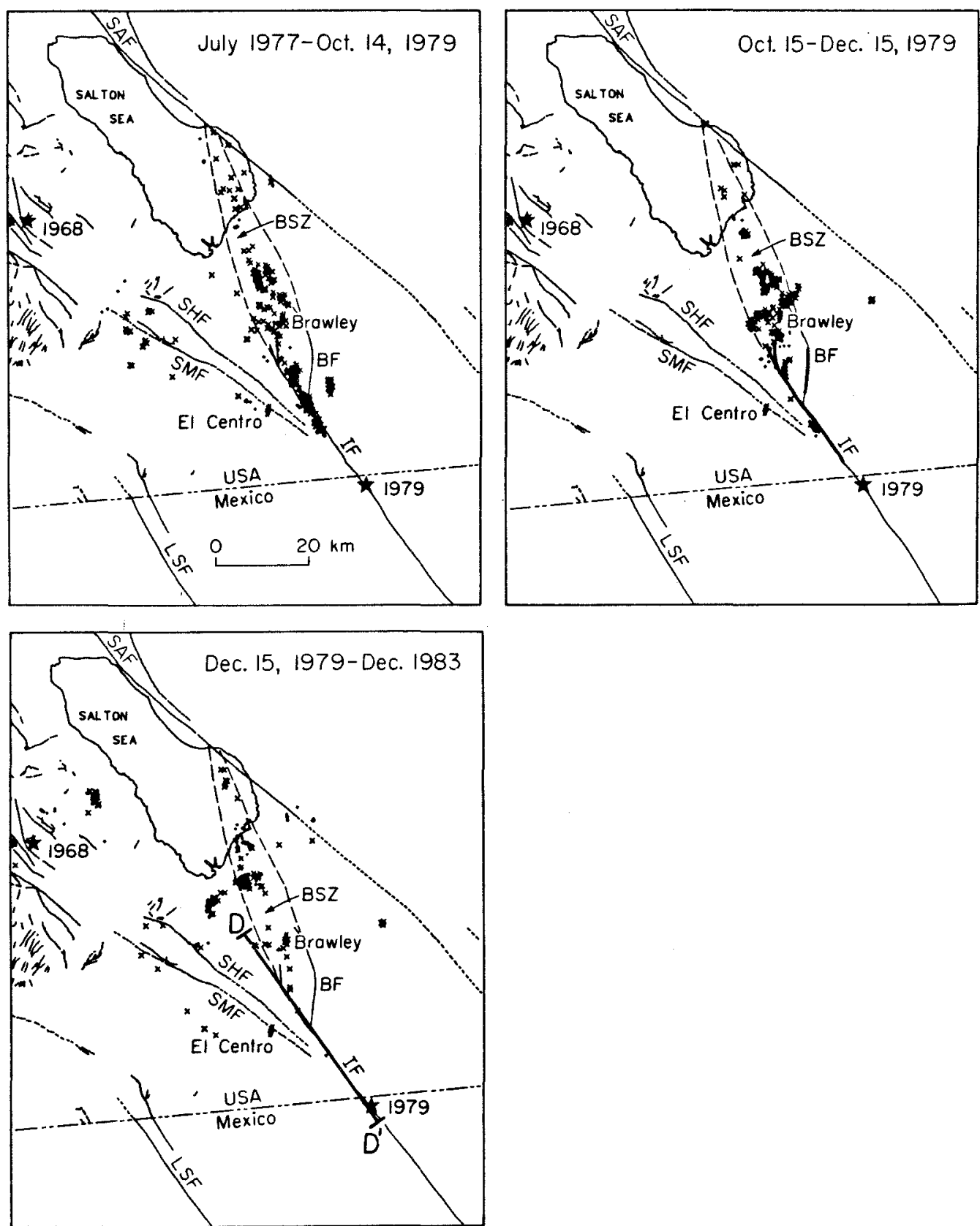

Fig. 11. Relocated seismicity in the Imperial Valley for three time periods as indicated. Bold lines drawn on the right-hand figure show surface faulting during the 1979 mainshock from Sharp et al. [1982]. Cross sections along D-D' are shown in Figures 13 and 15.

The Caltech catalog locations show a preponderance of aftershocks at greater depths as well. This suggests that the aftershocks, especially smaller aftershocks, are related to strain readjustment at the base of the seismogenic zone. The majority of larger aftershocks occurred at the northern end of the observed surface faulting or in the Brawley seismic zone along fault segments that did not rupture during the mainshock. These aftershocks were shallower than aftershocks that occurred along fault segments that ruptured during the mainshock.

Figure 13 shows cross sections of relocated seismicity within $5 \mathrm{~km}$ either side of the trace of the Imperial fault for the premainshock, aftershock, and post-December 15 , 1979, time periods. Note that point DL on the figures

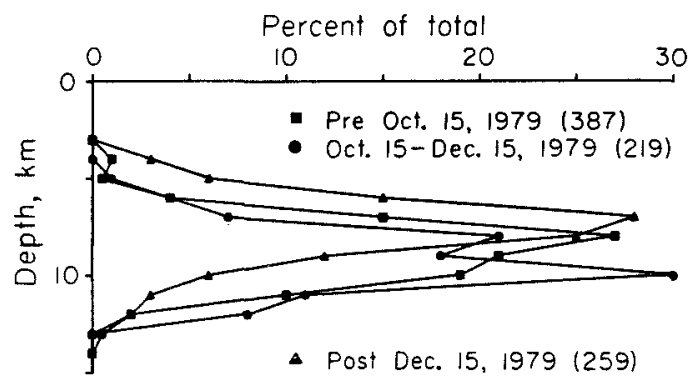

Fig. 12. Depth-frequency distribution for the three time periods shown in Figure 11. 
represents the southern limit of earthquakes that could be adequately located with the existing seismic network. The location of the 1979 mainshock hypocenter, the U.S.Mexican border, and the ends of the surface rupture are shown for reference. Since the southern end of the surface rupture and the mainshock hypocenter are south of point DL, no earthquake relocations are available to study seismic behavior in these regions. The northern end of the surface rupture occurs in the area of deepest seismicity along the Imperial fault, near the northern end of the subbasement high detected by Fuis et al. [1982]. The southern end of the dome probably is $3-5 \mathrm{~km}$ south of the intersection of the Brawley and Imperial faults. It is interesting to note that the region near the southern end of the dome is the region where the Imperial fault undergoes a transition from stick-slip behavior to the southeast to aseismic fault creep to the northwest [Reilinger, 1984]. The deepening of seismicity to the northwestward, along the portion of the Imperial fault that appears to be creeping, is opposite to the pattern along the creeping segment of the central San
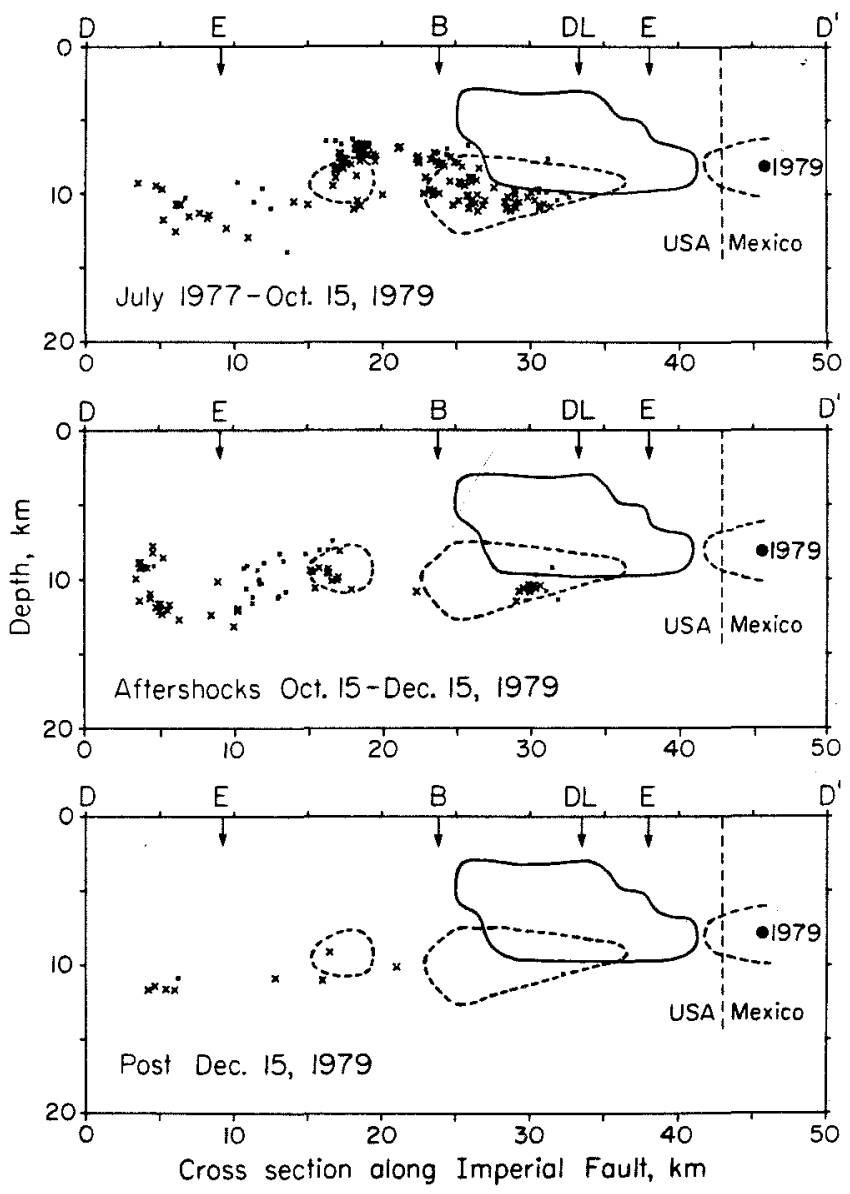

Fig. 13. Cross sections of seismicity along the strike of the Imperial fault (D-D', Figure 11) for the three time periods indicated. The large black dot is the hypocenter for the October 15, 1979, mainshock [Archuleta, 1982]. The vertical dashed line is the U.S.-Mexican border. E denotes the ends of the surface faulting observed during the mainshock [Sharp et al., 1982], B the intersection of the Brawley fault with the Imperial fault, and DL the limit for accurately determining focal depths using the Caltech network. The regions of the fault outlined by solid and dashed lines represent strike-slip offsets of $1 \mathrm{~m}$ from the faulting models of Hartzell and Heaton [1983] and Archuleta [1984], respectively.
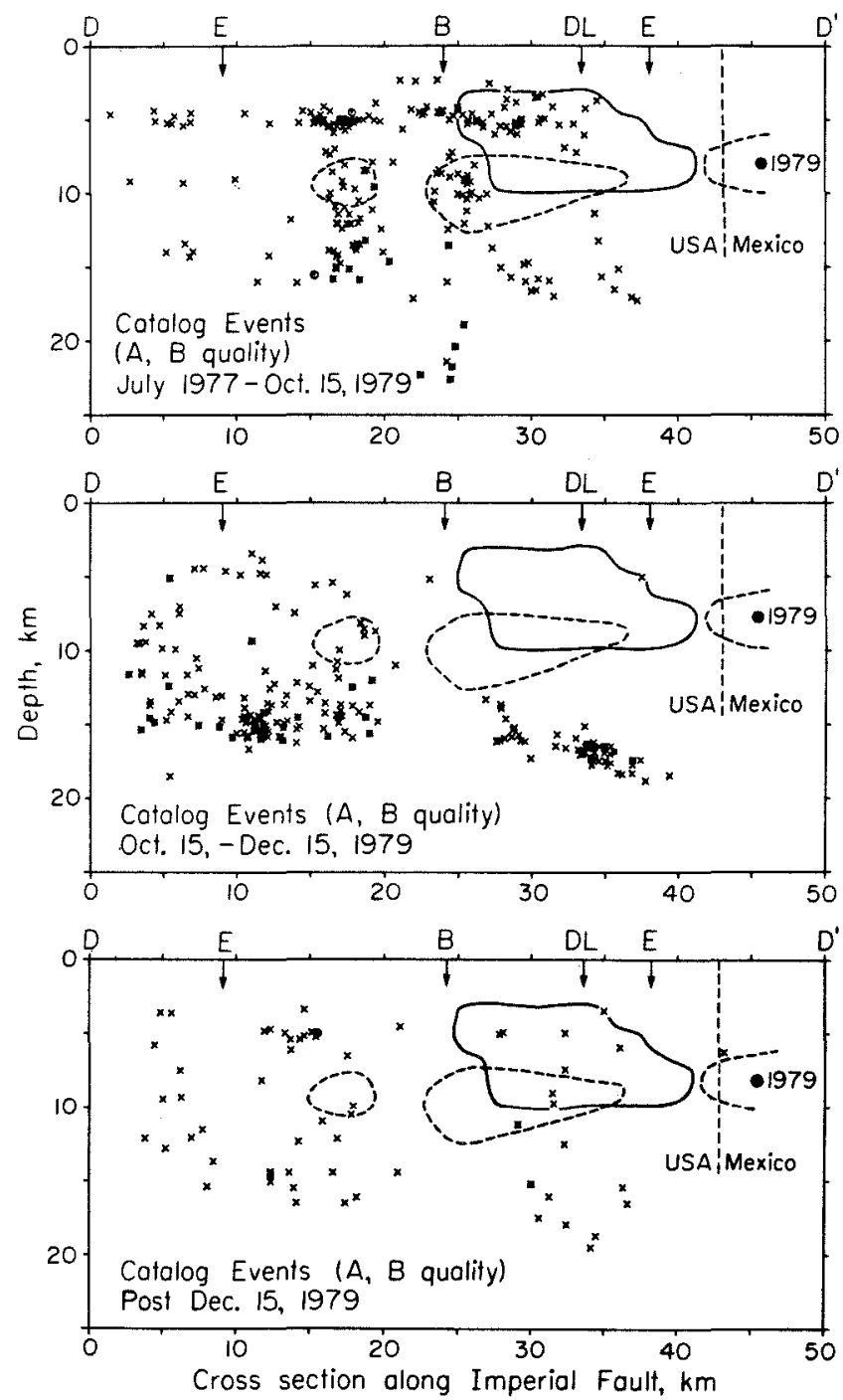

Fig. 14. Cross sections of A and B quality Caltech catalog seismicity along the strike of the Imperial fault (D-D', Figure 11) for the same time periods shown in Figure 13. Notation is the same as in Figure 13. These cross sections illustrate the spatial extent of the catalog seismicity but should not be interpreted as accurate representations of seismicity versus depth for reasons outlined in the text.

Andreas fault. Along the central San Andreas fault, maximum focal depths become shallower from the locked ends of the segment toward the creeping portion of the fault [Lindh and Boore, 1981].

Fuis et al. [1982] detected a 0.5 - to 1.0 -km-high fault scarp at a depth of $4-5 \mathrm{~km}$ that extends along the Imperial fault from $9 \mathrm{~km}$ north-northeast of El Centro to at least 12 $\mathrm{km}$ southeast of El Centro. They do not see evidence for the scarp $5 \mathrm{~km}$ to the north along the northern end of the surface trace of the Imperial fault. The end of the scarp at depth occurs in the region where earthquakes begin to deepen along the fault.

Figure 13 also shows strike-slip offsets of $\geq 1 \mathrm{~m}$ from the faulting models of Archuleta [1984] and Hartzell and Heaton [1983]. Both models have large patches of slip along the fault just south of the intersection of the fault with the Brawley fault. Smaller patches of slip are present to the north of this intersection and near the hypocenters in Archuleta's model. The major difference between the 


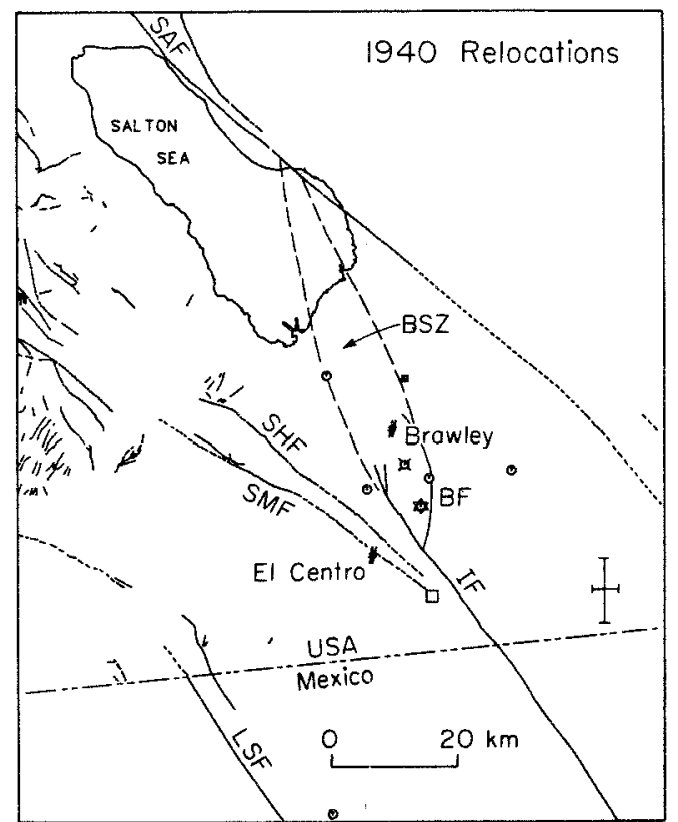

Fig. 15. Relocations of the 1940 mainshock (star) and aftershocks. The symbols for magnitude are the same as in Figure 2. The circle with a cross is a $M=5.5$ aftershock. The error bars represent error in relocating calibration events. The square is Richter's [1958] mainshock epicenter.

models is the depth of the slip zone. Hartzell and Heaton's model shows slip between depths of 6 and $10 \mathrm{~km}$ with slip $>1.4 \mathrm{~m}$ concentrated between 6 and $8 \mathrm{~km}$. Comparison of this model with relocated earthquakes indicates that few earthquakes from 1977 to 1983 occurred in this region of high slip. This suggests that this portion of the fault slipped only during the mainshock. Archuleta's model, however, shows maximum slip concentrated between 8 and $13 \mathrm{~km}$ in depth. Prior to the 1979 earthquake a large number of earthquakes occurred along this part of the fault. Aftershocks occurred in a small cluster within the region of high slip but not within the region of maximum slip. There have been few earthquakes along the Imperial fault south of the Brawley fault from 1980 to 1983 . The northern ends of the areas of maximum slip lie near the intersection of the Brawley fault and the edge of the subbasement high. Sharp et al. [1982] observed an $8^{\circ}$ change in the strike of the observed 1979 surface faulting at the northern end of the region of high slip.

Figure 14 shows $A$ and B quality events from the Caltech catalog for the same time periods as shown in Figure 13. Figure 14 illustrates the spatial extent of the catalog data and should not be interpreted as an accurate representation of seismicity with depth. Epicenters may be artificially concentrated at a depth of $5 \mathrm{~km}$ in these cross sections for reasons discussed in a previous section. The cross section demonstrates that the spatial variations seen in the relocated seismicity may also be seen in the catalog data and are not an artifact of the relocation process. A similar epicentral distribution exists in the $C$ and D quality catalog events for the same time periods, suggesting that $\mathrm{A}$ and $B$ quality events are a representative data set of the seismicity along the fault.

\section{Relation Between the 1940 and 1979 Imperial Valley Earthquakes}

Although the epicenter for the $1940\left(\mathrm{M}_{\mathrm{S}}=7.1\right)$ Imperial Valley earthquake [Richter, 1958] is poorly constrained, its approximate location indicates that the mainshock sequence started along the same portion of the fault where maximum slip occurred during the 1979 earthquake. In an effort to understand better the faulting process during the 1940 earthquake sequence we have relocated the mainshock and a number of aftershocks.

Three magnitude 4.0-5.5 earthquakes occurring between 1977 and 1979 that were well recorded at regional distances were used as calibration events by fixing their hypocenters and calculating station delays for stations operating in both 1940 and 1977 to 1979 . Although the 1940 mainshock was recorded at 11 California stations, only three stations (Riverside, Palomar, and La Jolla) had impulsive $P$ wave arrivals for the calibration events and delays of less than 2 $\mathrm{s}$. Stations beyond Riverside had delays of 4-6 $\mathrm{s}$ and were not used in the relocations with the exception of Tucson, which had a consistent delay for the calibration events as well as other selected aftershocks of the 1979 sequence. The calibration events were relocated using only these four stations and stations delays. The resulting epicenters were within $7 \mathrm{~km}$ of the original locations. Relocations of the 1940 earthquakes are shown in Figure 15. Many aftershocks that occurred south of the border were not well located. However, most of the northern aftershocks lie within or near the Brawley seismic zone to the north of the mainshock. The mainshock epicenter $\left(35^{\circ} 52.42^{\prime} \mathrm{N}\right.$, $115^{\circ} 29.08^{\prime} \mathrm{W}$ ) is $10 \mathrm{~km}$ north of Richter's epicenter. Error bars on Figure 15 reflect the error in locating the calibration events.

Another test of resolution was made by fixing the mainshock epicenter at 5 arc min intervals on a grid between $115^{\circ} 15^{\prime} \mathrm{W}$ and $115^{\circ} 45^{\prime} \mathrm{W}$ and $32^{\circ} 30^{\prime} \mathrm{N}$ and $33^{\circ} 15^{\prime} \mathrm{N}$ and calculating theoretical $\mathrm{P}$ travel time differences between the three nearest stations. The results of this test suggest that resolution in the north-south direction is between 5 and $7 \mathrm{~km}$, whereas in the east-west direction it is between 10 and $15 \mathrm{~km}$.

Figure 16 shows the our relocation of the 1940 mainshock with respect to the 1979 aftershocks. This location suggests that the 1940 earthquake began north of the main patch of slip during the 1979 mainshock and south of the region of deep seismicity associated with the subbasement high. Surface displacements north of the border for both the 1940 and 1979 earthquakes were similar [Sharp, $1982 \mathrm{~b}$ ]. Based on their analysis of strong motion records, Trifunac and Brune [1970] interpret the 1940 earthquake as a multiple sequence with at least four events occurring within the first $25 \mathrm{~s}$ of the sequence. They locate the first three of these events $0-10 \mathrm{~km}$ southeast of Richter's epicenter for the mainshock and the fourth event at the southern end of the 1940 surface rupture. They obtain epicentral location errors of $\pm 5 \mathrm{~km}$ by constraining the

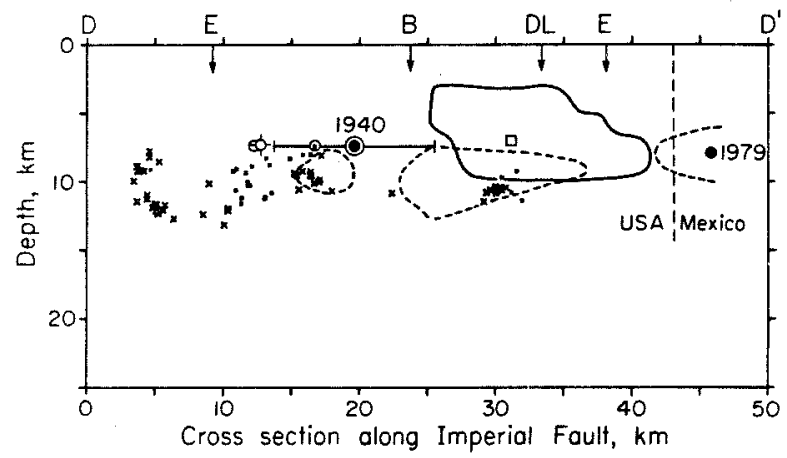

Fig. 16. Cross section along the Imperial fault with 1940 mainshock, aftershocks, and 1979 aftershocks. The square indicates Richter's [1958] epicenter. 
events to lie along the Imperial fault southeast of the El Centro accelerograph. This places the first three events along the portion of the fault where maximum slip occurred in 1979, although the surface displacement in 1940 was greater south of the U. S.-Mexican border. These observations suggest that the 1940 rupture began just to the north of the portion of the fault where maximum slip occurred in 1979 and that the initial event of the mainshock sequence may have ruptured the same portion of the fault that ruptured in $\mathbf{1 9 7 9}$

\section{Conclusions}

The study of the focal depths of over 1000 relocated earthquakes in the Imperial Valley-southern Peninsular Ranges has revealed four important relationships.

First, regional variations in focal depth appear to be related to regional variations in heat flow. In the Imperial Valley, where the average heat flow is nearly twice that of the Peninsular Ranges, seismicity peaks at a depth of $7 \mathrm{~km}$ compared to a peak of $11 \mathrm{~km}$ in the Peninsular Ranges. The deepest seismicity in the study area is associated with the regions of lowest heat flow.

Second, a deep region of seismicity at the northern end of the Imperial fault is associated with a heat flow low and a subbasement dome. The depth extent of the heat flow low is uncertain. However, rheologic modeling suggests that the subbasement dome alone may be sufficient to deepen the seismicity in this region. Insufficient knowledge of the crustal structure in the southern Peninsular Ranges precludes use of rheologic modeling to determine what factors influence small-scale focal depth variations in this region

Third, comparison of the focal depth distribution of earthquakes occurring before and after the October 15, 1979 , mainshock indicated that aftershocks in the first 2 months following the mainshock are $2-3 \mathrm{~km}$ deeper than pre-Qctober 15,1979 , or post-December 15,1979 , earthquakes. This suggests that the immediate aftershocks served to readjust strain near the base of the seismogenic zone. Following the mainshock, earthquakes are nearly absent from the portions of the fault that were modeled to have dislocations of $\geq 1 \mathrm{~m}$ during the mainshock.

Fourth, the relocated epicenter of the 1940 mainshock is located to the north of the region of maximum slip on the Imperial fault during the 1979 mainshock and suggests that the 1940 mainshock sequence began with rupture along this same portion of the fault.

Acknowledgments. We would like to thank A. Frankel and S. Wesnousky for their helpful discussions and comments. T. Webb wrote many of the programs used in accessing the phase data. A. Lachenbruch kindly provided us with a preprint of the Salton Trough heat flow paper. J. Pechmann and M. Baker reviewed a preliminary version of the manuscript. Comments by an anonymous reviewer and an associate editor were also appreciated. This work was supported by U.S. Geological Survey contract 14-080001-21981. D. Doser was also supported by a Caltech Bantrell postdoctoral fellowship. Contribution 4258, Division of Geological and Planetary Sciences, California Institute of Technology, Pasadena.

\section{References}

Anderson, J.G., and P.G. Silver, Accelerogram evidence for southward rupture propagation on the Imperial fault during the October 15, 1979 earthquake, Geophys. Res. Lett., 12, 349-352, 1985.

Archuleta, R. J., Hypocenter for the 1979 Imperial Valley earthquake, Geophys. Res Lett, 9 , 625-628, 1982.
Archuleta, R. J., A faulting model for the 1979 Imperial Valley earthquake, J. Geophys. Res, $\underline{89}$, 4559-4585, 1984.

Brace, W. F., Some new measurements of linear compressibility of rocks, J. Geophys. Res., 70, 391-398, 1965.

Brace, W. F., and D. L. Kohlstedt, Limits on lithospheric stress imposed by laboratory experiments, J. Geophys. Res., 85, 6248-6252, 1980.

Caristan, Y., The transition from high-temperature creep to fracture in Maryland diabase, J. Geophys. Res., 87, 6781-6798, 1982

Clark, S. P., Jr., Thermal conductivity, Handbook of Physical Constants, section 21, edited by S. P. Clark, Jr., Mem. Geol. Soc. Amer., 97, 459-482, 1966.

Clark, S. P., Jr., Z. E. Peterman, and K. S. Heier, Abundances of uranium, thorium and potasssium, Handbook of Physical Constants, section 24, edited by S. P. Clark, Jr., Mem. Geol. Soc. Amer., 97, 521-542, 1966.

Combs, J., and D. M. Hadley, Microearthquake investigation of the Mesa geothermal anomaly, Imperial Valley, California, Geophysics, $42,17-33,1977$.

Corbett, E. J., Seismicity and crustal structure studies of southern California: Tectonic implications from improved earthquake locations, $\mathrm{Ph}$. D. thesis, $231 \mathrm{pp}$., Calif. Inst. of Technol., Pasadena, 1984

Dibblee, T. W., Jr., Geology of the Imperial Valley region, California, Geology of the Natural Provinces, chapter 2, Geology of Southern California, edited by R. H. Jahns, Calif. Div. Mines Bull., 170, 21-28, 1954.

Ebel, J. E., and D. V. Helmberger, $\mathrm{P}$ wave complexity and fault asperities, The Borrego Mountain California earthquake of 1968, Bull. Seismol. Soc. Am. 2, 413-437, 1982.

Fuis, G. S., and M. Schnapp, The November-December 1976 earthquake swarms in northern Imperial Valley, California: Seismicity on the Brawley fault and related structures (abstract), Eos Trans. AGU, 58, 1188, 1977.

Fuis, G. S., W. D. Mooney, J. H. Healy, G. A. McMechan, and W. J. Lutter, Crustal structure of the Imperial Valley region, The Imperial Valley, California, Earthquake of October 15, 1979, U.S. Geol Surv. Prof. Pap. 1254, $25-49,1982$

Gilpin, B., and T.-C. Lee, A microearthquake study in the Salton Sea geothermal area, California, Bull. Seismol. Soc. Am, 68, 441-450, 1978

Green, S. M., Seismotectonic study of the San Andreas, Mission Creek, and Banning fault system, M. S. thesis, 50 pp., Univ. of Calif., Los Angeles, 1983.

Hamilton, R. M., Time-term analysis of explosion data from the vicinity of the Borrego Mountain, California, earthquake of 9 April, 1968, Bull. Seismol. Soc. Am. $\underline{60}$, $31-54,1970$

Hamilton, R. M., Aftershocks of the Borrego Mountain earthquake from April 12 to June 12, 1968, in the Borrego Mountain Earthquake of April 9, 1968, U.S. Geol. Surv Prof Pap, 787, 31-54, 1972.

Hartzell, S. H., and T. H. Heaton, Inversion of strong ground motion and teleseismic waveform data for the fault rupture history of the 1979 Imperial Valley, California, earthquake, Bull. Seismol. Soc. Am., $\underline{73}, 1553-$ 1584, 1983.

Hill, D. P., P. Mowinckel, and K. M. Lahr, Catalog of earthquakes in the Imperial Valley, California, June 1973-May 1974, U.S.Geol. Surv. Open File Rep., 75-401, 29 pp., 1975a.

Hill, D. P., P. Mowinckel, and L. G. Peake, Earthquakes, active faults, and geothermal areas in the Imperial Valley, California, Science, $188,1306-1308,1975 \mathrm{~b}$.

Johnson, C. E., CEDAR-An approach to the computer automation of short-period local seismic networks; seismotectonics of the Imperial Valley of southern Cali- 
fornia, Ph. D. thesis, 343 pp., Calif. Inst. of Technol, Pasadena, 1979.

Johnson, C. E., and D. M. Hadley, Tectonic implications of the Brawley earthquake swarm, Imperial Valley, California, January 1975, Bull. Seismol. Soc. Am., 66, 1133$1144,1976$.

Johnson, C. E. , and L. K. Hutton, Aftershocks and preearthquake seismicity, The Imperial Valley, California, Earthquake of October 15, 1979, U.S. Geol. Surv. Prof. Pap., 1254, 59-76, 1982.

Lachenbruch, A. H., J. H. Sass, and S. P. Galanis, Jr., Heat flow in southernmost California and the origin of the Salton Trough, J. Geophys. Res., 90, 6709-6736, 1985.

Lee, W. H. K., and J. C. Lahr, HYPO71(revised): A computer program for determining hypocenter, magnitude and first motion pattern of local earthquakes, U.S. Geol. Surv. Open File Rep., 113 pp., 1975.

Lindh, A. G., and D. M. Boore, Control of rupture by fault geometery during the 1966 Parkfield earthquake, Bull. Seismol. Soc. Am, 71, 95-116, 1981.

Meissner, R., and J. Strehlau, Limits of stresses in continental crusts and their relation to the depth-frequency distribution of shallow earthquakes, Tectonics, 1 , 73-89, 1982.

Pechmann, J. C., and H. Kanamori, Waveforms and spectra of preshocks and aftershocks of the 1979 Imperial Valley, California, earthquake: Evidence for fault heterogeneity?, J.Geophys. Res., 주, 10,579-10,598, 1982.

Reilinger, R., Coseismic and postseismic vertical movements associated with the 1940 M7.1 Imperial Valley, California, earthquake, J. Geophys. Res., $\underline{89}$, 4531-4538, 1984.

Renner, J. L., D. E. White, and D. L. Williams, Hydrothermal convection systems, Assessment of Geothermal Resources of the United States-1975, edited by D. E White and D. L. Williams, U.S. Geol. Surv. Circ., 720, 5-57, 1975.

Richter, C. F., Elementary Seismology, W. H. Freeman, San Francisco, Calif., 1958.

Sanders, C. O., and H. Kanamori, A seismotectonic analysis of the Anza Seismic Gap, San Jacinto fault zone, southern California, J. Geophys. Res., 89, 5873$5890,1984$.

Sass, J. H., S. P. Galanis, Jr., A. H. Lachenbruch, B. V. Marshall, and R. J. Munroe, Temperature, thermal conductivity, heat flow and radiogenic heat production from unconsolidated sediments of the Imperial Valley, California, U.S. Geol. Surv. Open File Rep. $\underline{84-490}, 38$ pp., 1984.

Sharp, R. V., Tectonic setting of the Salton Trough, The
Borrego Mountain Earthquake of April 9, 1968, U.S. Geol. Surv. Prof. Pap, 787, 3-15, 1972.

Sharp, R. V., Tectonic setting of the Imperial Valley region, The Imperial Valley, California, Earthquake of October 15, 1979, U.S. Geol. Surv. Prof. Pap., 1254, 5$14,1982 \mathrm{a}$.

Sharp, R. V., Comparison of 1979 surface faulting with earlier displacements in the Imperial Valley, The Imperial Valley, California, Earthquake of October 15, 1979, U.S. Geol. Surv. Prof Pap. 1254, 213-221, 1982b.

Sharp, R. V., J. J. Lienkaemper, M. G. Bonilla, D. B. Burke, B. F. Fox, D. G. Herd, D. M. Miller, D. M. Morton, D. J. Ponti, M. J. Rymer, J. C. Tinsley, J. C. Yount, J. E. Kahle, E. W. Hart, and K. E. Sieh, Surface faulting in the central Imperial Valley, The Imperial Valley, California, Earthquake, October 15, 1979, U.S. Geol. Surv. Prof. Pap., 1254, 119-144, 1982.

Sibson, R. H., Frictional constraints on thrust, wrench, and normal faults, Nature, 249, 542-544, 1974

Sibson, R. H., Fault zone models, heatflow, and the depth distribution of earthquakes in the continental crust of the United States, Bull. Seismol. Soc. Am. 72, 151-163, 1982.

Smith, R. B., and R. L. Bruhn, Intraplate extensional tectonics of the eastern Basin-Range: Inferences on structural style from seismic reflection data, regional tectonics, and thermal-mechanical models of brittle-ductile deformation, J. Geophys. Res., 89, 5733-5762, 1984.

Thatcher, W., and R. M. Hamilton, Aftershocks and source characteristics of the 1969 Coyote Mountain earthquake, San Jacinto fault zone, California, Bull. Seismol.Soc. Am, 63, 647-661, 1973

Trifunac, M. D., and J. N. Brune, Complexity of energy release during the Imperial Valley, California, earthquake of 1940, Bull. Seismol. Soc. Am., 60, 137-160, 1970.

Turcotte, D. L., and G. Schubert, Geodynamics, $450 \mathrm{pp}$., John Wiley, New York, 1982.

Weaver, C. S., and D. P. Hill, Earthquake swarms and local crustal spreading along major strike-slip faults in California, Pure Appl. Geophys., 117, 51-64, 1979.

D.I. Doser and H. Kanamori, Seismological Laboratory, California Institute of Technology, Pasadena, CA, 91125 .

(Received April 17, 1985; revised October 7,1985 ; accepted October 11, 1985.) 